

\title{
OCIDENTALIZAÇÃO DOS DIREITOS HUMANOS E EXCLUSÕES ABISSAIS: ANÁLISE DAS PRÁTICAS DISCURSIVAS E DO EXERCÍCIO DO PODER NO DIREITO INTERNACIONAL
}

\author{
WESTERNIZATION OF HUMAN RIGHTS AND ABYSSAL EXCLUSIONS: ANALYSIS \\ ON DISCURSIVE PRACTICES AND POWER EXERCISE IN INTERNATIONAL LAW \\ OCCIDENTALIZACIÓN DE LOS DERECHOS HUMANOS Y EXCLUSIONES \\ ABISALES: ANÁLISIS DE LAS PRÁCTICAS DISCURSIVAS Y DEL EJERCICIO DEL \\ PODER EN EL DERECHO INTERNACIONAL
}

\author{
Robert Augusto de Souza \\ Mestrando em Direito (USP) \\ Universidade de São Paulo (USP) \\ robert.souza@usp.br \\ OrcidID: https://orcid.org/0000-0001-7683-0068 \\ Karol Natasha Lourenço Castanheira \\ Doutora em Comunicação (UNESP) \\ Universidade do Estado de Minas Gerais (UEMG) \\ karol.castanheira@uemg.br \\ OrcidID: https://orcid.org/0000-0002-0337-6084 \\ Vinicius Fernandes Ormelesi \\ Doutor em Filosofia e Teoria Geral do Direito (USP) \\ Universidade do Estado de Minas Gerais (UEMG) \\ vinicius.ormelesi@uemg.br \\ OrcidID: http://orcid.org/0000-0002-6511-328X
}

Resumo: O artigo propõe problematizar a "ocidentalização" dos direitos humanos na atualidade a partir da análise dos mecanismos discursivos e jurídicos mobilizados pelo Ocidente para construir regimes de verdade em âmbito internacional, dos quais se destacam o direcionamento da comunicação midiática e a manipulação de instrumentos normativos internacionais. Nesse contexto, elencamos como objetivo geral demonstrar a existência de uma construção de sentido ocidental e hegemônica na práxis jurídica da comunidade internacional, pela qual valores distintos são imputados às lesões aos direitos humanos e à inobservância às normas globais de proteção a depender dos atores envolvidos nesses acontecimentos. Como objetivos específicos, pretendemos (i) compreender como a divulgação midiática de atentados terroristas opera para consolidar práticas discursivas orientalistas; (ii) aferir como o instituto da legítima defesa tem sido usado para proteger 
interesses ocidentais; (iii) avaliar os critérios de valoração da morte na guerra e em atentados terroristas; e (iv) discutir o lugar da guerra na definição orçamentária das potências ocidentais, especificamente os Estados Unidos. Em termos metodológicos, a pesquisa é empírica e qualitativa, fundamentada na pesquisa bibliográfica e documental, e aplica o método indutivo, sendo que, quanto à sua estrutura, o artigo se divide em cinco seções. Quanto aos resultados, esperamos contribuir para as discussões sobre a superação de desigualdades na esfera jurídica, refletindo sobre o lugar da ocidentalização nas relações de poder no cenário internacional e, em sentido amplo, na construção de uma produtividade ocidentalizada das dimensões jurídicas e sociais.

Palavras-chave: Direitos humanos. Ocidentalização. Orientalismo. Discurso. Poder.

Abstract: The article proposes to problematize the "westernization" of human rights today by analyzing the discursive and juridical mechanisms the West mobilizes to formulate regimes of truth in the international level, of which the tempering of media communication and the manipulation of international normative instruments are on the spotlight. In this context, our main goal is to demonstrate the existence of a western and hegemonic construction of sense in the legal praxis of the international community, through which human rights violations and non-compliance with global protection standards are valued differently depending on the actors involved in these events. As specific objectives, we intend to (i) comprehend how media diffusion of terrorist attacks helps consolidating orientalist discursive practices; (ii) find out how self-defense has been used to protect Western interests; (iii) assess the valuation criteria for death in war and in terrorist attacks; and (iv) discuss the role of war in the budgetary definitions of Western powerful nations, specifically the United States. Methodologically, we propose a qualitative empirical research, based on bibliographic and documental analysis, applying the inductive method to a five-section article. Regarding results, we hope to contribute to the discussions on inequalities in the juridical sphere, reflecting upon the role of westernization in power relations in the international scene and, in a broader sense, in the making of a westernized production of the social and juridical dimensions.

Keywords: Human rights. Westernization. Orientalism. Discourse. Power.

Resumen: El artículo propone problematizar la "occidentalización" de los derechos humanos en la actualidad desde un análisis de los mecanismos movilizados por el Occidente para construir regímenes de verdad en la esfera internacional, de los cuales se destacan el direccionamiento de la comunicación mediática y la manipulación de instrumentos normativos internacionales. En este contexto, elegimos como objetivo general demostrar la existencia de una construcción de sentido occidental y hegemónica en la praxis jurídica de la comunidad internacional, por la cual valores distintos son imputados a las violaciones de derechos humanos y a la inobservancia a las normas globales de protección dependiendo de los actores envueltos en estas ocurrencias. Como objetivos específicos, buscamos (i) comprender como la divulgación mediática de atentados terroristas actúa para consolidar prácticas discursivas orientalistas; (ii) verificar como el instituto de la legítima defensa ha sido utilizado para proteger intereses occidentales; (iii) examinar los criterios de valoración de la muerte en la guerra y en atentados terroristas; y (iv) discutir el lugar de la guerra en la definición presupuestaria de las potencias occidentales, específicamente los Estados Unidos. En termos metodológicos, la investigación es empírica y cualitativa, fundada en estudio bibliográfico y documental, aplica el método inductivo, dividiéndose el artículo en cinco secciones. Cuanto a los resultados, intentamos contribuir para las discusiones acerca de la 
superación de desigualdades en la esfera jurídica, reflexionando sobre el lugar de la occidentalización en las relaciones de poder en ámbito internacional y, en sentido amplio, en la construcción de una productividad occidentalizada de las dimensiones jurídicas y sociales.

Palabras-clave: Derechos humanos. Occidentalización. Orientalismo. Discurso. Poder.

\section{Introdução 1}

Com o fim da Segunda Guerra Mundial, a cena geopolítica internacional foi reconfigurada, especialmente pelo anseio das diversas nações em evitar a repetição dos acontecimentos então superados. Diante disso, a Organização das Nações Unidas foi fundada em 1945, ao que se seguiu a redação da Declaração Universal dos Direitos Humanos, publicada em 1948, a qual passaria a servir como farol para a construção do sistema internacional de proteção dos direitos humanos, balizado por uma variedade de convenções, protocolos e tratados que formalizaram e especificaram os mecanismos de salvaguarda de direitos nos mais diversos âmbitos.

Entretanto, a nova formulação da cartografia internacional não evitou que graves lesões aos direitos humanos voltassem a ocorrer, sendo perpetradas, inclusive, pelos mesmos países que se obrigaram a defender as garantias fundamentais reconhecidas ainda na primeira metade do século XX. De fato, a análise do panorama internacional da época e dos processos que levaram à aprovação da Carta da ONU e da própria Declaração Universal revelam que, embora estabelecidas enquanto instrumentos globais, os pilares da sociedade internacional contemporânea não foram erguidos de maneira coletiva e plural. Ao contrário, os termos dessas Cartas de Direitos foram definidos por um seleto grupo de países, os quais trasladaram para o novo sistema internacional um domínio já exercido na formação global anterior.

Exemplo dessa realidade é a composição do Conselho de Segurança das Nações Unidas, único órgão internacional legitimado para tomar medidas de eficácia vinculante lastreadas pelo uso da força. Formado por quinze membros, o Conselho tem cinco cadeiras permanentes $^{2}$ em sua composição, cujos ocupantes são titulares de poder individual de veto sobre as propostas de Resolução levadas à apreciação do colegiado.

$\mathrm{Na}$ mesma linha, o discurso também não está imune à concepção dominante irradiada do Ocidente. Em verdade, a análise atenta dos meios de comunicação explicita

\footnotetext{
${ }^{1}$ Agradecemos à Fundação de Amparo à Pesquisa do Estado de Minas Gerais (FAPEMIG) pelo financiamento do projeto de pesquisa cujos resultados são comunicados neste artigo.

${ }^{2}$ São membros permanentes do Conselho de Segurança das Nações Unidas a China, os Estados Unidos da América, a França, a Rússia e o Reino Unido. Por sua vez, os membros temporários são eleitos pela Assembleia Geral da ONU para mandatos de dois anos. 


\section{OCIDENTALIZAÇÃO DOS DIREITOS HUMANOS E EXCLUSÕES ABISSAIS: ANÁLISE \\ DAS PRÁTICAS DISCURSIVAS E DO EXERCÍCIO DO PODER NO DIREITO

destaques e ocultamentos sobre lesões a direitos humanos em circunstâncias semelhantes, embora envolvendo atores e contextos geopolíticos distintos.

Diante disso, este trabalho se põe como um processo reflexivo-descritivo a fim de situar um locus de discussão acerca da instrumentalização dos mecanismos de força e a função de poder que se constitui na aplicabilidade dos Direitos Humanos.

Assim, investigaremos a produção discursiva, como um dos instrumentos de força que ordena o sentido dos acontecimentos sociais, apontando as discrepâncias de enquadramento e tipificações a eventos ocorridos em ou instigados, seja por um caráter de resposta ao ocidentalismo ou na tentativa de agenciamentos, por países orientais.

Pretende-se também discutir o regramento jurídico da legítima defesa no âmbito internacional e investigar os custos humanos e econômicos dos conflitos armados deflagrados ou integrados pelos países do Ocidente, em especial os Estados Unidos, a fim de aferir a ocorrência de uma distorção dos Direitos Humanos em prol de interesses ocidentais.

Para tanto, a pesquisa se valerá do método indutivo, analisando situações particulares a fim de identificar o panorama geral da chamada "ocidentalização" e o comportamento dos diversos atores envolvidos nessa problemática.

Partindo do ferramental oferecido por autores como Boaventura de Sousa Santos, Michel Foucault e Edward Said e recorrendo, ainda, à pesquisa documental, o trabalho se desdobra em cinco etapas. Na primeira delas, discutimos brevemente as características do orientalismo, buscando abordar como o conhecimento e a cultura ocidentais vêm sendo construídos ao longo da história com pretensões de uniformização global.

Em seguida, nos dedicamos a analisar como o medo, potencializado por regularidades discursivas alimentadas pela abordagem midiática do terrorismo e pelos ocupantes de cargos públicos, se reflete na opinião popular e na legitimação da guerra.

$\mathrm{Na}$ terceira fase, discorremos sobre a evolução da legítima defesa no direito internacional moderno, reconstruindo seu percurso formativo na jurisprudência da Corte Internacional de Justiça e na interpretação conferida ao instituto pelos Estados Unidos após os atentados de 11 de setembro de 2001.

Já na quarta etapa, buscamos problematizar os critérios de definição da relevância das vidas em âmbito internacional. Para fazê-lo, quantificamos o número de mortes ocorridas em conflitos armados deflagrados após o ataque às Torres Gêmeas e em atentados terroristas ocorridos ao redor do mundo desde então, bem como recorremos a estudos e a documentos oficiais produzidos sobre o fluxo orçamentário direcionado à guerra. 


\section{OCIDENTALIZAÇÃO DOS DIREITOS HUMANOS E EXCLUSÕES ABISSAIS: ANÁLISE \\ DAS PRÁTICAS DISCURSIVAS E DO EXERCÍCIO DO PODER NO DIREITO \\ INTERNACIONAL}

Por fim, nos apoiamos no substrato empírico analisado para promover uma discussão acerca das possibilidades e desafios para o futuro sob a luz das exclusões abissais.

Em termos de resultados e impactos, esperamos demonstrar a ocorrência de uma "ocidentalização" dos direitos humanos, derivada das interpretações e preconcepções coloniais continuamente lançadas sobre "o Oriente" e da negação sistemática dos atributos de humanidade dos povos colonizados, o que se pode observar na discrepância valorativa (tanto em números como pelo foco midiático) entre as mortes em atentados terroristas e o estrato do silêncio e das intervenções militares (de questionada legalidade) praticados pelas potências ocidentais no Oriente.

\section{Ocidente e orientalismo}

$\mathrm{Na}$ esteira dos estudos pós-coloniais, o escrutínio do fenômeno da ocidentalização se vincula à hipótese de que a civilização ocidental (ou, em melhores termos, as sociedades ocidentais que ostentam maior influência cultural, política e socioeconômica no advento da modernidade) irradia vontades de verdade e regimes de exercício do poder (FOUCAULT, 1979; 1980; 2005) que submetem a cidadania e a afastam a aplicabilidade de direitos dos seres às margens do padrão existencial defendido pelo Ocidente.

Esse processo de relativização se manifesta tanto no seio (multi)cultural como na práxis jurídica da comunidade internacional, vez que valores distintos são imputados às lesões aos direitos humanos e à inobservância às normas globais de proteção a depender dos atores envolvidos nesses acontecimentos.

Isso se deve, em grande medida, à atuação imperialista do Ocidente na instauração das colonizações e no avanço da globalização, cujo desenlace está refletido no sistema internacional de proteção dos direitos humanos, na concepção das subjetividades e na exigibilidade do direito a ter direitos.

Partindo disto, apresenta-se um questionamento fundamental: como opera o Ocidente na construção discursiva dos sujeitos e na produção do próprio direito?

Segundo Santos (2009), cumpre deslocar a análise da indagação sobre “o que é” o Ocidente para a investigação das nuances de seu engendramento histórico-social e de sua formatação operacional, quer dizer, das maneiras pelas quais o Ocidente pauta e difunde seu projeto de existência em escala global.

Para respondê-lo, partimos do entendimento de que o Ocidente não está configurado de maneira homogênea e de que sua constituição não deriva de um processo 


\section{OCIDENTALIZAÇÃO DOS DIREITOS HUMANOS E EXCLUSÕES ABISSAIS: ANÁLISE \\ DAS PRÁTICAS DISCURSIVAS E DO EXERCÍCIO DO PODER NO DIREITO

histórico linear e unilateral. De fato, aquilo que hoje se conhece como Ocidente parte do avanço colonizador da Europa ocidental no final do século XVI, a partir do que uma determinada visão de mundo, ancorada em valores e instituições específicos, logrou êxito em se impor como soberana ao resto do globo e assim se consolidar ao longo dos séculos seguintes (GOODY, 2006; SANTOS, 2009; WALLERSTEIN, 2007).

Para tanto, fez-se necessário exortar agenciamentos políticos e sociais de apagamento e mistificação das culturas e saberes divergentes do regime de verdade que se firmava enquanto único e absoluto, pelo que foi tracejada uma linha de exclusões abissais (SANTOS, 2007; ARAÚJO, 2016), que se presta a isolar "os outros" do campo de visão existencial, relegando-os ao espaço para além das margens do palco social assimilável.

Considerando o extrato das colonizações, a revelar um firmamento das potências ocidentais nas posições globais de maior relevância, tem-se um claro sucesso do Ocidente $^{3}$ em manter vigente a sua teleologia, projetando em sua história "alguma característica ou recurso único que explicaria a preponderância ocidental no mundo atual e a certeza linear de sua trajetória futura" (SANTOS, 2009, p. 107) e conservando no tempo o poder de imprimir um caráter universalizante aos seus ditames culturais, econômicos, políticos e sociais.

No entanto, essa tentativa de monopolizar as fontes de conhecimento, quer dizer, de exigir que sejam entendidos como verdade tão somente os saberes emanados do mundo ocidental, não passa pela história sem enfrentamento, sendo que a guerra tem se mostrado um dos instrumentos mais acionados para acossar a dissidência e fazê-la permanecer em sua condição indiscernível.

Apesar de sua permanência histórica, essa dinâmica atingiu novos patamares após os atentados de 11 de setembro e o início da Guerra "ao Terror". Como reação imediata aos ataques, foi (e ainda tem sido) deflagrada uma torrente de significações de morte contra o “Oriente", representado no ideário popular pelas comunidades islâmica e muçulmana, transformando o estereótipo de atraso em noção de perigo iminente.

Entretanto, deve-se questionar: o que é o Oriente?

Ao contrário da imaginação fomentada pelos padrões ocidentais de existência, a interpretação comumente conferida ao Oriente não é produto de uma animosidade inerente ou de um subdesenvolvimento deliberado; pelo contrário, trata-se de uma representação, da invenção da essência pelo Oriente, de um meio de conformar sua dominação pelo Ocidente a partir das múltiplas formas em que este negocia a existência daquele (SAID, 2007).

\footnotetext{
${ }^{3}$ Compreendido enquanto a Europa Ocidental e seus "herdeiros", precipuamente os Estados Unidos da América. 
Dada a condição histórica de produção desses regimes de veridicção (FOUCAULT, 1999; 2010), que têm determinado quais tipos de existência podem ser assumidos como dignos (ou, no limite, como "verdadeiros"), as contínuas iniciativas de subalternização impostas ao Oriente longo dos séculos, ultrapassam a mera casualidade dos interesses econômicos, mas se prestam a definir, em última análise, a legitimidade para definir as condutas e os saberes tidos por aceitáveis em escala global (CHOMSKY, 2016).

Vale destacar que a construção deste discurso negativo remonta também à criação da antropologia no século XIX. Surgindo como um saber atrelado ao imperialismo, inicialmente a antropologia estará a serviço da justificação da dominação colonial do Oriente "selvagem" pelo Ocidente "civilizado". É de se notar também que a própria imagem do Ocidente se forma por meio da construção negativa do "outro", o não europeu, o primitivo.

Neste sentido, a antropologia funcionaria como uma das mais importantes rubricas acadêmicas sobre a alteridade para a disseminação do discurso teórico do dominante acerca do dominado, na medida em que o "Oriente, ao menos na forma como o conhecemos por meio do Orientalismo, é uma criação do discurso, fabricada na Europa e exportada de volta para o Oriente. A representação é ao mesmo tempo uma forma de criação e uma forma de exclusão" (HARDT; NEGRI, 2000, p. 125).

Isso leva a crer que, por mais que o Oriente tenha experimentado momentos de breve emancipação ao longo dos últimos anos, principalmente na cultura e no turismo, os processos de captura ocidentais são difíceis de serem desativados no plano internacional quando se resvala em questões bélicas, principalmente.

Com efeito, principalmente após a construção do Estado de Israel, o Ocidente (em especial os EUA) tem praticado uma série de ações militares que, sob a luz do discurso oficial, se voltam à democratização e à pacificação das regiões afetadas (GOODMAN, 2006), mas que se caracterizam pelo controle de influências e, para além disso, pelo domínio dos recursos naturais (em especial o petróleo) existentes nos países afetados pelas intervenções.

Aí também se insere o Direito no instrumental de dominação (FOUCAULT, 1976; 1998) arregimentado pelo imperialismo ocidental para obter preponderância nas relações de poder. A toda evidência, a ordem jurídica também tem servido como instrumento de dominação do Ocidente no campo geopolítico, seja pela imposição de uma carta de direitos humanos de matriz eurocêntrica aos países do Oriente (ARAÚJO, 2016), a justificar 


\section{OCIDENTALIZAÇÃO DOS DIREITOS HUMANOS E EXCLUSÕES ABISSAIS: ANÁLISE DAS PRÁTICAS DISCURSIVAS E DO EXERCÍCIO DO PODER NO DIREITO

intervenções de natureza aparentemente humanitária, ou pela uniformização interpretativa das normas relativas ao uso da força sob a égide técnica do Direito Internacional ${ }^{4}$.

Atentamos, ainda, para o fato de que não somente "o Oriente" anunciado por Said é confrontado pelo Ocidente hegemônico. Com efeito, o gládio existencial Norte-Sul explicitado por Santos (1995) denota a persistente relação colonial de exploração e expropriação econômica e etnocultural perpetrada por nações do "Norte global" contra os países do Sul, aos quais se inflige uma espécie de "colonização epistêmica".

Para todos os efeitos, entende-se que as relações Norte-Sul estão diretamente associadas ao imperialismo ocidental e, portanto, vinculadas ao pensamento abissal, na medida em que o projeto imperial engendrado pelo Ocidente acarreta também o lançamento das existências do Sul ao espaço de invisibilidade subalterna, isto é, ao "outro lado da linha". Buscamos aclarar a operacionalização dessa realidade nas seções seguintes.

\section{Enquadramentos midiáticos}

Ao contrário dos animais irracionais, o ser humano extrai de sua vivência no mundo a necessidade de proteção de si e dos seus de maneira constante, ainda que na ausência de ameaça genuína ou iminente. Por força desse medo derivado (BAUMAN, 2007), alguém que esteja inserido num contexto de insegurança e vulnerabilidade está sujeito a que seu corpo produza, por autopropulsão, reações instintivas a um encontro imediato com o perigo ainda que ele não exista de fato.

No contexto internacional, ameaça cada vez mais alardeada do terrorismo exemplifica essa situação. Diante de um cenário de medo permanente, as populações dos Estados têm atingido níveis elevadíssimos de desconfiança em relação ao diferente ${ }^{5}$, o que tem acarretado um aumento exponencial dos esforços de securitização ao redor do globo.

Esse debate tem ocupado espaço de destaque na literatura, que tem apontado a existência de uma associação implícita entre terrorismo e descendência do Oriente Médio e do Islã no pensamento ocidental (ALSULTANY, 2012; GOTTSCHALK; GREENBERG, 2008; PARK; FELIX; LEE, 2007; SALEEM; ANDERSON, 2013) e uma ênfase nos estereótipos

\footnotetext{
${ }^{4}$ Vale destacar que a própria terminologia nação é derivada do contexto europeu e o entendimento da ideia de estados nacionais remonta à Paz de Westfália de 1648. Ressalte-se ainda ser o direito internacional moderno um fruto do ius commune europeu desenvolvido na Idade Média pela escola dos comentadores, resultado de um amálgama entre o direito romano, o direito canônico e os direitos estatutários. Posteriormente, o direito comum daria origem ao ius inter gentes, proposto por Hugo Grócio, do qual deriva o direito internacional moderno.

${ }^{5}$ Daí os contínuos relatos de xenofobia, em que a aversão a imigrantes tem levado até mesmo à adoção de medidas restritivas à entrada de pessoas oriundas de países "suspeitos". 
associados à diferença e ao terrorismo mesmo nos retratos considerados neutros sobre descendentes do Oriente Médio (AKBARZADEK; SMITH, 2005).

A imbricação dessas narrativas dominantes (SULTAN, 2016) na abordagem do terrorismo tem encontrado respaldo também no âmbito das pesquisas quantitativas.

Partindo da premissa de que a nacionalidade do perpetrador impacta na cobertura midiática (WEIMANN; BROSIUS, 1991) e usando dados da Global Terrorism Database 6 entre 2006 e 2015 e coletando artigos das plataformas LexisNexis Academic e da CNN.com, Kearns, Betus e Lemieux (2019) analisaram 136 episódios de terrorismo retratados em 3.541 artigos de notícia, o que lhes permitiu chegar a quatro hipóteses:

a. Ataques terroristas recebem mais cobertura midiática quando o perpetrador é muçulmano do que quando o perpetrador não é muçulmano.

b. Ataques terroristas recebem mais cobertura midiática quando o perpetrador é preso do que quando o perpetrador não é preso.

c. Ataques terroristas recebem mais cobertura midiática quando o alvo é um edifício ou grupo de servidores governamental do que quando o alvo é não governamental.

d. Ataques terroristas recebem mais cobertura midiática à medida que o número de fatalidades aumenta.

Com o término das análises, o estudo chegou às seguintes conclusões:

- Se o perpetrador é muçulmano, há em média 357\% mais notícias sobre o ataque;

- Há um aumento de $287 \%$ na cobertura quando o perpetrador é preso;

- Se o alvo é governamental, há um aumento médio de $46 \%$ na cobertura, por ataque;

- Quando os indivíduos ou o grupo responsável pelo ataque são desconhecidos, há uma redução de $70 \%$ na cobertura.

Ainda, utilizando-se de desagregação de dados e a estimativa a partir dos resultados iniciais, os pesquisadores verificaram que o aumento da cobertura midiática em razão da origem muçulmana varia de acordo com o perfil do meio de comunicação.

\footnotetext{
${ }^{6}$ Trata-se da mais completa plataforma de sistematização neutra do terrorismo em escala global e a nível incidental, cujos dados iniciais remontam a 1970 e chegam à atualidade. 


\section{OCIDENTALIZAÇÃO DOS DIREITOS HUMANOS E EXCLUSÕES ABISSAIS: ANÁLISE DAS PRÁTICAS DISCURSIVAS E DO EXERCÍCIO DO PODER NO DIREITO

Quando se trata de fontes secundárias de notícia, o aumento é de $\mathbf{2 2 8 \%}$, enquanto que as fontes majoritárias de notícia ${ }^{7}$ registram um aumento alarmante de $\mathbf{7 5 8 \%}$, o que demonstra que a cobertura de ataques terroristas por muçulmanos recebe muito mais destaque em escala nacional do que em nível local. Em sentido oposto, as demais variáveis permanecem estáveis qualquer que seja o meio.

Gráfico 1 - Aumento percentual em cobertura por atributos dos ataques e por tipo de fonte

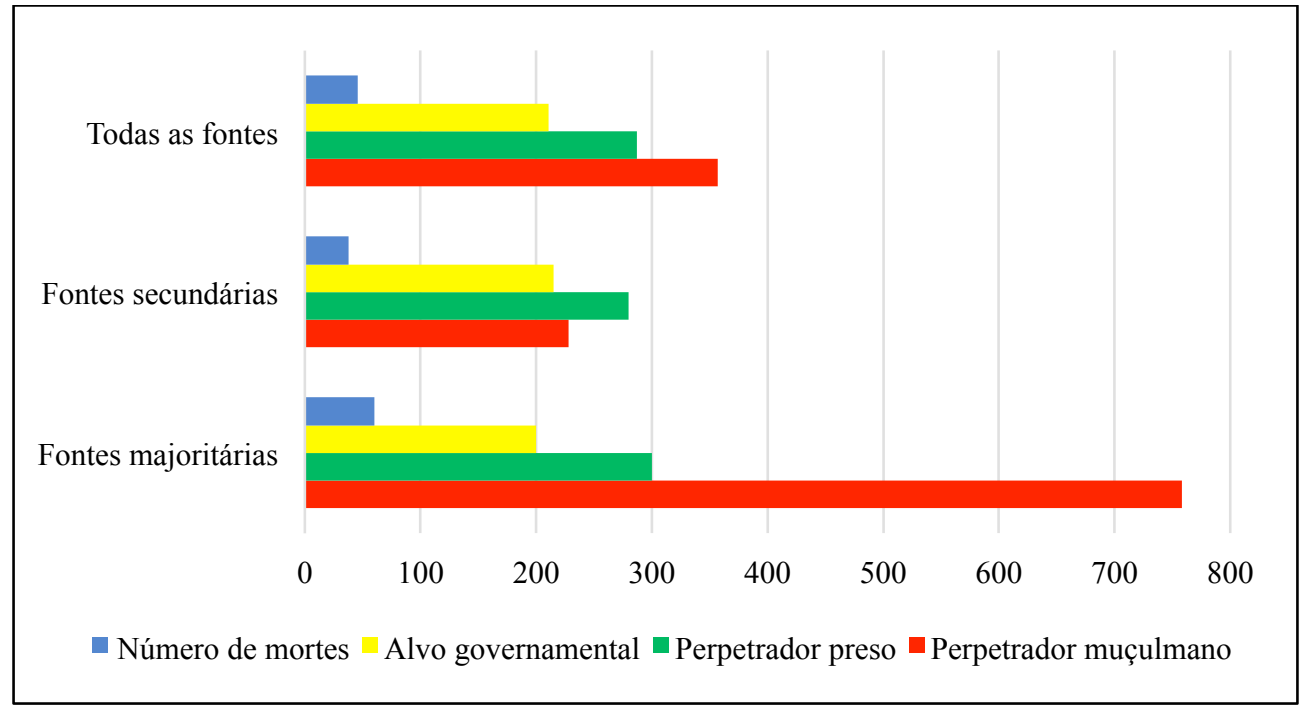

Fonte: KEARNS; BETUS; LEMIEUX, 2019.

Em termos práticos, o número de mortes demonstra ser um critério muito menos importante do que a origem dos perpetradores dos ataques quando da incidência da atuação midiática sobre os atentados. De fato, o gráfico acima assinala que a quantidade de vidas perdidas é praticamente insignificante quando confrontada à origem do agente criminoso.

Neste mesmo sentido, um estudo conduzido pelo AlJazeera Centre of Studies (2016) verificou que a abordagem midiática e a quantidade de cobertura de atentados terroristas são diretamente influenciadas pela localização das empresas de comunicação, pelo reconhecimento global das cidades envolvidas, pela frequência dos eventos naqueles sítios específicos e pelo grau de empatia do público atingido em relação às vítimas do ataque no tocante às suas características pessoais.

Ainda, a discrepância entre os percentuais de aumento da cobertura nas fontes secundárias e majoritárias corrobora a tese defendida neste artigo no sentido de que, em certa medida, os grandes veículos de comunicação instrumentalizam as regularidades discursivas impostas ao Oriente e, por conseguinte, fortalecem a subjugação daqueles que lá habitam.

\footnotetext{
${ }^{7}$ O estudo adota como fontes majoritárias de notícia o New York Times, o Wall Street Journal, o Washington Post, o USA Today e a CNN, enquanto que todas as outras fontes consultadas são consideradas secundárias. 
É o que reafirmam Kearns, Betus e Lemieux:

\begin{abstract}
Ainda que talvez de forma não intencional, parece improvável que as disparidades baseadas em raça e religião na cobertura da mídia de entretenimento sejam coincidências. A cobertura midiática pode explicar as percepções do público sobre terrorismo e identidade. Evidências sugerem que, para os norteamericanos, há uma associação implícita entre terrorismo, pessoas descendentes do Oriente Médio e o Islã [...]. No Reino Unido, muçulmanos - particularmente aqueles nascidos no estrangeiro - são crescentemente considerados uma ameaça à segurança nacional [...]. Huff e Kertzer (2017) descobriram que os cidadãos são mais suscetíveis a entender um ataque como terrorismo quando o perpetrador é muçulmano. De modo similar, quando apresentados em notícias sobre crimes reais, incidentes cometidos por muçulmanos apresentaram maior probabilidade de serem definidos como terrorismo e também foram julgados mais severamente [...]. (KEARNS; BETUS; LEMIEUX, 2019, p. 5-6)
\end{abstract}

Essa atuação direcionada dos meios de comunicação ocidentais opera, como um mecanismo de propagação massificada do orientalismo, à medida que a retratação do terrorismo como um crime eminentemente muçulmano corrobora os processos de subjetivação ocidentalmente produzidos contra o indivíduo não ocidental.

Não bastasse, a cobertura midiática de ameaças à segurança nacional impacta não só a opinião pública (SLONE, 2001), mas tem o potencial de direcionar as decisões políticas tomadas a respeito (GILBOA, 2005). Daí que, se entendemos que os líderes das potências ocidentais necessitam de certa aprovação popular para declarar uma guerra ou para desencadear intervenções militares e que o próprio terrorismo é mais efetivo quando recebe cobertura midiática disseminada (POWELL, 2011), uma vez que um número maior de pessoas é atingido pela mensagem que se busca enviar no atentado, pode-se dizer que os objetivos das potências coloniais são igualmente beneficiados pela cobertura massificada, já que a opinião popular influenciada pelo frenesi é tendente a aceitar de bom grado medidas de proteção do território nacional e de intervenção no território inimigo.

Nessa linha de raciocínio, a feitura da guerra, muito antes das movimentações militares, passa necessariamente por outra disputa: aquela travada pelo domínio do discurso, em que os enunciados manifestos veiculam um já-dito, segundo o qual o território a ser invadido abriga (pela lógica epistemologicamente dominante) seres inferiores, e postulam a aceitação de um jamais-dito, por força do qual a intervenção seria necessária em prol de interesses econômicos e políticos não pronunciados (FOUCAULT, 2007). 


\section{OCIDENTALIZAÇÃO DOS DIREITOS HUMANOS E EXCLUSÕES ABISSAIS: ANÁLISE DAS PRÁTICAS DISCURSIVAS E DO EXERCÍCIO DO PODER NO DIREITO

O esforço de militarização das relações internacionais em favor dos interesses do Ocidente passa, portanto, pela injeção de um valor marcial (CHOMSKY, 2014) nos sujeitos, sendo que dois momentos na história recente dos Estados Unidos nos demonstram a produção deste valor marcial: as ações norte-americanas na Nicarágua e no Iraque em 1984 e 2002, respectivamente.

Os desdobramentos fáticos das ações estadunidenses em ambos os casos, bem como os meandros jurídicos da questão da defesa, serão abordados em maior detalhe na próxima seção.

\section{Direito internacional hegemônico}

A legítima defesa, inerente instrumento de violência, deriva de uma agressão injusta, a qual se busca repelir. No panorama internacional, em especial na realidade das Nações Unidas, pode-se considerar que as ameaças à paz, a ruptura da paz e os atos de agressão (elementos fundantes do Capítulo VII da Carta das Nações Unidas) são fatores que afastariam a pacificidade na solução de controvérsias e autorizariam o uso da força, ultima ratio no que tange às prerrogativas do Conselho de Segurança.

Neste sentido, o artigo 51 da Carta estabelece:

Artigo 51. Nada na presente Carta prejudicará o direito inerente de legítima defesa individual ou coletiva no caso de ocorrer um ataque armado contra um Membro das Nações Unidas, até que o Conselho de Segurança tenha tomado as medidas necessárias para a manutenção da paz e da segurança internacionais. As medidas tomadas pelos Membros no exercício desse direito de legítima defesa serão comunicadas imediatamente ao Conselho de Segurança e não deverão, de modo algum, atingir a autoridade e a responsabilidade que a presente Carta atribui ao Conselho para levar a efeito, em qualquer tempo, a ação que julgar necessária à manutenção ou ao restabelecimento da paz e da segurança internacionais.

Há, pois, o direito à legítima defesa a todo membro das Nações Unidas que for alvo de um ataque armado. Isto significa, em termos práticos, a necessidade de uma lesão efetiva legitimar a defesa, em detrimento da possibilidade de atuação prévia, que, como há de se verificar mais adiante, é um cenário que recorrentemente se delineia, ainda que questionável às margens da legalidade e à custa do princípio da não intervenção.

$\mathrm{Na}$ contramão desta realidade, o Pacto da Sociedade das Nações, organismo antecessor da ONU, somente permitia a ação beligerante unilateral em uma particularidade restrita: a incapacidade de aprovação unânime do parecer produzido por seu Conselho a 


\section{OCIDENTALIZAÇÃO DOS DIREITOS HUMANOS E EXCLUSÕES ABISSAIS: ANÁLISE \\ DAS PRÁTICAS DISCURSIVAS E DO EXERCÍCIO DO PODER NO DIREITO

respeito da conflagração levada à sua apreciação, o que demonstrava um interesse da entidade no abandono da belicosidade em favor da adoção de medidas pacíficas na solução de controvérsias e da pluralização dos meios de prevenção, resolução e sanção direcionados aos conflitos bi ou multilaterais, conforme as disposições do Artigo 15, parágrafo $7^{\circ}$ do Pacto:

\footnotetext{
Artigo 15: [...]

7. No caso em que o Conselho não consiga fazer aceitar seu relatório por todos os seus membros, exclusive os representantes de qualquer das partes litigantes, os membros da Sociedade reservam-se o direito de proceder como julgarem necessário para a manutenção do direito e da justiça.
}

A incongruência entre esses dispositivos revela que a Carta das Nações Unidas adotou uma postura de maior liberdade em relação à permissividade do uso da força, antes subsumido à aplicação pretérita de disposições de solução coletiva dos conflitos em escala internacional.

Não sem motivo, essa abertura nos critérios de licitude do uso da força teve papel relevante nos atos beligerantes praticados pelos Estados a partir da criação da ONU. De fato, as grandes potências (em especial os Estados Unidos da América) têm sucessivamente se posicionado como legitimadas para usar a força em prol da manutenção da segurança, ainda que de forma unilateral (o financiamento de ações paramilitares na Nicarágua pelos EUA e a atuação da OTAN, também capitaneada pelos EUA, no Kosovo comprovam essa afirmativa).

Essas intenções se tornaram evidentemente mais claras após o atentado de 11 de setembro de 2001, na medida em que o ataque ao World Trade Center consubstanciou a primeira ameaça palpável não só à segurança nacional dos Estados Unidos, mas ao establishment hegemônico do mundo ocidental (CHOMSKY, 2002).

Esse redirecionamento, surpreendente em sua improbabilidade, trouxe às relações internacionais o desafio de se adaptarem a uma realidade que rompeu com um ciclo aparentemente inquebrantável, construído a partir da supremacia norte-americana eclodida nas duas Guerras Mundiais e consolidada com o fim da Guerra Fria, em que o sistema econômico planificado foi derrubado junto ao Muro de Berlim.

$\mathrm{O}$ ataque às Torres Gêmeas, à época consideradas um símbolo absoluto do capitalismo e da influência dos EUA, provocou reflexos transcendentes ao plano material, visto que o sucesso do atentado demonstrou ao mundo a quebra da invulnerabilidade de uma nação que, até então, se revelava inconteste.

Este foi o estopim para que a Casa Branca tomasse a iniciativa de publicizar a nova Estratégia de Segurança Nacional dos Estados Unidos, redesenhada face ao "novo 


\section{OCIDENTALIZAÇÃO DOS DIREITOS HUMANOS E EXCLUSÕES ABISSAIS: ANÁLISE DAS PRÁTICAS DISCURSIVAS E DO EXERCÍCIO DO PODER NO DIREITO

inimigo" e marco da Doutrina Bush, causadora de um grande enfraquecimento na coletividade internacional e da ebulição do isolacionismo ora atenuado desde o crepúsculo do conflito entre Leste e Oeste na década anterior:

[...] defender os Estados Unidos, o povo Americano, e nossos interesses internos e externos pela identificação e destruição da ameaça antes que chegue a nossas fronteiras. Enquanto os Estados Unidos vão constantemente batalhar para arregimentar o suporte da comunidade internacional, não hesitaremos em agir sozinhos, caso necessário, para exercer nosso direito de legítima defesa agindo preemptivamente contra esses terroristas, de forma a impedi-los de causar danos ao nosso povo e ao nosso país. (EUA, 2002, p. 6 , grifo nosso)

Esse posicionamento de agressão dos EUA é reforçado pela criação de novas disposições legais a respeito da legítima defesa e do uso da força (tais como o Patriot Act e a Lei de Proteção dos Membros do Serviço), pelas quais o intervencionismo é tratado como possibilidade concreta e o instituto da preempção é reiteradamente discursivizado:

Por séculos, o direito internacional reconhece que as nações não precisam sofrer um ataque antes que possam legalmente tomar medidas para se defender contra forças que apresentem um perigo iminente de ataque. Doutrinadores e juristas internacionais usualmente condicionaram a legitimidade da preempção à existência de uma ameaça iminente precipuamente a mobilização visível de exércitos, esquadras, e forças aéreas se preparando para atacar.

Devemos adaptar o conceito de ameaça iminente às capacidades e objetivos dos adversários atuais. [...]

Os Estados Unidos têm longamente mantido a opção de ações preemptivas para conter uma ameaça suficiente à nossa segurança nacional. Quanto maior a ameaça, maior o risco de inação - e mais persuasivo o caso para a tomada de ação antecipada para nos defender, ainda que haja incerteza acerca do tempo e do lugar do ataque inimigo. Para antecipar ou prevenir tais atos hostis de nossos adversários, os Estados Unidos agirão, caso necessário, preemptivamente. (EUA, 2002, p. 15, grifo nosso)

O que há de se contestar, no entanto, é a natureza do que a Doutrina $\mathrm{Bush}^{8}$ nomeou como defesa preemptiva, cuja construção interpretativa leva à legitimação da defesa nos casos de iminência de um ataque (MURPHY, 2005), de forma a evitar os danos que seriam causados por ele. Ainda assim, deve-se elucidar os limites deste limiar, ou seja, saber o

\footnotetext{
${ }^{8}$ A iniciativa encabeçada pelo Presidente dos Estados Unidos em prol da legitimação da noção de legítima defesa preemptiva para fins de uso da força após o atentado às Torres Gêmeas ficou conhecida no meio político e na literatura especializada em Direito Internacional como "Doutrina Bush". Cf. DIAS, 2007. 


\section{OCIDENTALIZAÇÃO DOS DIREITOS HUMANOS E EXCLUSÕES ABISSAIS: ANÁLISE DAS PRÁTICAS DISCURSIVAS E DO EXERCÍCIO DO PODER NO DIREITO

quão preemptivas são as ações tomadas pelos EUA e perceber o momento em que essa barreira é ultrapassada e o cenário que se configura é o de prevenção, e não de preempção?

A defesa preventiva significa a ação ou intervenção militar que se pratica sem que haja rastro visível de um ataque em iminência de ocorrer (BUCHANAN; KEOHANE, 2007; REISMANN, 2003), e aí jaz sua ilicitude. Considerando que a ingerência é, via de regra, proibida pela ordem jurídica internacional, é necessário equacionar as consequências práticas de sua aplicação caso não preenchidos os requisitos da legítima defesa e do uso da força.

A questão já foi alvo de debates na jurisprudência internacional. Ao julgar o caso relativo às ações militares e paramilitares praticadas na República da Nicarágua, a Corte Internacional de Justiça rejeitou a justificativa de legítima defesa coletiva suscitada pelos Estados Unidos e reiterou a inobservância aos preceitos de não intervenção e da vedação ao uso da força contra outros Estados (CIJ, 1986; SORTO, 1995).

No caso, foi reconhecido a violação às normas de direito internacional pelos EUA devido ao financiamento do grupo paramilitar "Contras" por parte do governo de Ronald Reagan com o objetivo de derrubar o regime sandinista na Nicarágua, apesar da proibição congressual de direcionamento orçamentário com essa finalidade ${ }^{10}$.

Apesar das alegações genéricas dos Estados Unidos acerca do suposto risco imposto pelo governo nicaraguense, a Corte reconheceu que a alimentação de um grupo armado ilegal, pautado pelo intuito declarado de derrubar os mandatários eleitos de uma outra nação, não poderia ser considerada uma forma de legítima defesa, já que os atos questionados não se enquadram às exceções permissivas previstas no direito internacional costumeiro ${ }^{11} \mathrm{e}$ daí implicariam violação ao jus ad bellum (DELAHUNTY; YOO, 2007).

Atentos à probabilidade de um julgamento desfavorável, os Estados Unidos não participaram da fase meritória da ação perante a Corte Internacional de Justiça, alegando que o Tribunal carecia de jurisdição para processar e julgar a causa. Apesar disso, a Corte prosseguiu no julgamento ${ }^{12}$ e condenou os EUA a reparar os danos causados à Nicarágua.

\footnotetext{
9 Ações preventivas apenas podem ser autorizadas pelo Conselho de Segurança da ONU. Neste sentido, acompanhamos o entendimento de Dias (2007), para quem a defesa supostamente preemptiva pregada pela Doutrina Bush é uma tentativa de se passar por legítima defesa, o que dispensaria a autorização do Conselho, quando na realidade são ações antecipatórias e, portanto, ilícitas à luz do Direito Internacional.

${ }^{10}$ Em 1984, o Congresso autorizou a disponibilização de US\$ 24 milhões para financiamento dos Contras. Já em 1985, após a baixa aprovação popular da iniciativa, o Parlamento vedou a aplicação de novos recursos na causa.

${ }^{11}$ A autodefesa em resposta a um ataque armado ou a ação militar deflagrada ou autorizada pelo Conselho de Segurança das Nações Unidas, nos termos dos artigos 49 a 51 da Carta.

12 Apesar da preliminar de incompetência manejada pelos EUA, a CIJ entendeu que detinha jurisdição para julgar a demanda uma vez que o caso foi levado à sua apreciação antes que se esgotasse o prazo de seis meses previsto na declaração unilateral que modificou as hipóteses de aceitação da jurisdição compulsória pelos EUA. 


\section{OCIDENTALIZAÇÃO DOS DIREITOS HUMANOS E EXCLUSÕES ABISSAIS: ANÁLISE DAS PRÁTICAS DISCURSIVAS E DO EXERCÍCIO DO PODER NO DIREITO

Nesse ponto surge uma outra ferramenta preponderante na manipulação do direito internacional à vista de interesses próprios: o poder de veto no Conselho de Segurança. Uma vez estabelecida a condenação na CIJ, a Nicarágua tentou exigir o cumprimento da obrigação perante o Conselho ${ }^{13}$, mas a iniciativa foi barrada pelo voto negativo dos EUA (ONU, 1986) tal como já fizera em oportunidades anteriores, nas quais a Nicarágua tentou levar ao Conselho a situação de interferência externa ${ }^{14}$.

A reprodução da iniciativa de veto em razão de interesses políticos próprios não é escassa na história do Conselho de Segurança. O alinhamento político dos EUA ao Estado de Israel, por exemplo, tem levado à sistemática rejeição de propostas tendentes a mitigar os efeitos deletérios da questão palestina justamente pelo veto estadunidense. No período entre 1973 e 2018, vinte e sete propostas sobre o assunto foram vetadas no Conselho, todas elas impedidas de obter êxito exclusivamente em razão do voto contrário dos EUA ${ }^{15}$.

Diante dessas evidências, e por mais que os EUA reiteradamente descrevam sua política externa como pautada pela democratização dos países alvo de suas ações e pelo fortalecimento da segurança internacional, essas alegações são um tanto quanto duvidosas.

Primeiro, pelo fato de que as ações militares praticadas pelos Estados Unidos não foram autorizadas pelo Conselho de Segurança. Em verdade, apesar da edição da Resolução n. 1.373 pelo Conselho dias após o atentado ao World Trade Center, não houve permissão do colegiado para a prática de atos de agressão por qualquer de seus membros, mas tão somente se determinou a tomada de medidas destinadas a prevenir e combater o terrorismo.

Ora, se o artigo 51 da Carta da ONU permite a prática de atos unilaterais de força tão somente em reação a ameaças vigentes, carecem de validade jurídica as ações militares deflagradas pelos EUA sob a bandeira da "Guerra ao Terror", notadamente a invasão ao Afeganistão e ao Iraque, ainda que fundamentadas no suposto combate intransigente ao terrorismo e na caçada dos perpetradores do atentado.

Desvios de legalidade semelhantes ocorrem em nome de ideais supostamente altruísticos. O jus in bello, também chamado Direito Internacional Humanitário (DIH), propõe

\footnotetext{
${ }^{13}$ A moção foi levada ao Conselho de Segurança na medida em que ele é o único órgão internacional cujas decisões são capazes de vincular os Estados.

${ }^{14}$ Destacam-se as propostas S/14941 (1982), S/16463 (1984).

${ }^{15}$ No período citado, a numeração indexada: S/10794 (1973), S/11940 (1976), S/12119 (1976), S/13911 (1980), S/14832/Rev.1 (1982), S/17730/Rev.2 (1986), S/19466 (1988), S/19780 (1988), S/20463 (1989), S/20677 (1989), S/20945/Rev.1 (1989), S/21326 (1990), S/1995/394 (1995), S/1997/199 (1997), S/1997/241 (1997), $\mathrm{S} / 2001 / 270$ (2001), S/2001/1199 (2001), S/2002/1385 (2002), S/2003/891 (2003), S/2003/980 (2003), S/2004/240 (2004), S/2004/783 (2004), S/2006/508 (2006), S/2006/878 (2006), S/2011/24 (2011), S/2017/1060 (2017), S/2018/516 (2018).
} 


\section{OCIDENTALIZAÇÃO DOS DIREITOS HUMANOS E EXCLUSÕES ABISSAIS: ANÁLISE \\ DAS PRÁTICAS DISCURSIVAS E DO EXERCÍCIO DO PODER NO DIREITO

uma vertente exceptiva do princípio da não intervenção, originada de um compromisso dos Estados em zelar pelos direitos humanos, com base num "princípio da guerra justa".

O DIH justificaria uma mitigação do princípio da não intervenção em prol da salvaguarda de direitos humanos em situações de violação, o que autorizaria os demais Estados a tomarem medidas de ingerência como base naquilo que se veio a definir como “responsabilidade de proteger" (NORHEIM-MARTINSEN, 2013), isto é, o dever dos Estados em defender os direitos humanos independentemente dos limites territoriais.

Entretanto, diversas intervenções tidas como humanitárias têm sido pano de fundo para a consecução de outros objetivos, dentre eles a desestabilização dos Estados atingidos pelo lado de dentro. Além disso, a inexistência de um sistema mínimo de freios e contrapesos (KÖCHLER, 2003; STROMSETH, 2003), a probabilidade da influência de interesses econômicos e políticos nos processos de tomada de decisão (GOLDSMITH; POSNER, 2006) e a possibilidade de que os Estados se valham dessa doutrina para tangenciar a competência do Conselho de Segurança (LOBEL; RATNER, 1999) têm provocado forte reticência quanto à aceitabilidade do instituto para fins de mitigação da norma cogente de não intervenção.

As críticas às intervenções humanitárias na Bósnia, na Líbia e no Kosovo ampliam esse campo de problematização. Para além do questionamento de eventuais intenções indiretas dos interventores, a doutrina da responsabilidade de proteger é colocada em xeque também pela gravidade dos danos provocados pelas ações militares de origem externa, as quais tendem a ampliar o número de mortes, a provocar ampla instabilidade moral e a potencializar retaliações pelo grupo político ou social colocado em desvantagem (KUPERMAN, 2008; 2013).

Em linhas gerais, essas evidências apontam que as ferramentas de atuação negativa (das quais se destaca o poder de veto) e positiva (as possibilidades de intervenção humanitária) oferecidas pelo direito internacional têm sido mobilizadas pelas potências ocidentais, em especial pelos Estados Unidos, em prol de interesses próprios, o que demonstra uma captura desses institutos pelos regimes de veridicção produzidos pelo Ocidente.

Além disso, a utilização do direito internacional enquanto instrumento de dominação tem provocado uma perda de legitimidade dos organismos internacionais de proteção aos direitos humanos e causado insegurança jurídica sem precedentes, na medida em que a amplitude semântica conferida aos conceitos de terrorismo e de risco à segurança internacional tem autorizado a adoção de medidas preventivas sem qualquer lastro indiciário, tais como a intervenção no Irã pelos Estados Unidos em razão da suposta existência de um programa nuclear (TERRY; OPENSHAW, 2013). 


\section{OCIDENTALIZAÇÃO DOS DIREITOS HUMANOS E EXCLUSÕES ABISSAIS: ANÁLISE DAS PRÁTICAS DISCURSIVAS E DO EXERCÍCIO DO PODER NO DIREITO \\ INTERNACIONAL}

\section{Ditos e não ditos do discurso}

O enfrentamento bélico e discursivo travado pelo Ocidente hegemônico contra os diferentes de si tem deixado rastros sangrentos. Como se sabe, as guerras civis deflagradas nos países do Oriente causaram (e ainda causam) milhares de mortes todos os anos, e a atuação imperialista das nações ocidentais contribui para um aumento vertiginoso do número de corpos caídos. De fato, o que se percebe pelo empilhamento dos cadáveres é que eventos em que muito menos pessoas morreram são lembrados com proeminência em relação a outros episódios em que grupos dezenas, às vezes centenas de vezes maiores, foram exterminados.

Talvez o maior exemplo dessa alegação seja o atentado ao World Trade Center. Até hoje, o Nine Eleven marca a história mundial, ao passo que iniciativas terroristas muito mais cruentas passam despercebidas aos noticiários e, em última análise, à atenção e ao conhecimento da população. Neste sentido, a tabela abaixo compara os números de mortos, refugiados e desalojados em oito acontecimentos diferentes, alguns deles pretéritos e alguns atuais, como é o caso da Guerra Civil na Síria. É possível que o leitor desconheça alguns desses episódios, apesar da monta do registro apresentado, como talvez a explosão de um carro-bomba no centro de Mogadishu, Somália, que deixou mais de 300 mortos e 500 feridos.

Ainda, o quadro abaixo visa a explicitar o impacto desses eventos a médio e longo prazo, o que se verifica nos números de refugiados e desalojados, de modo a corroborar a tese de que a quantidade de pessoas atingidas não é diretamente proporcional ao relevo discursivo que se confere à questão.

Tabela 1 - Quadro comparativo de casualidades

\begin{tabular}{|c|c|c|}
\hline Evento & Mortos & Refugiados e desalojados \\
\hline Nine Eleven & 2.996 & 0 \\
\hline Ataque em Paris & 130 & 0 \\
\hline Ataque em Barcelona & 13 & 0 \\
\hline Ataque em Beirute & 43 & 0 \\
\hline Ataque em Mogadishu & $300+$ & 5.000 .000 \\
\hline Guerra no Afeganistão e no Paquistão & 173.000 & 3.000 .000 \\
\hline Guerra no Iraque & 461.000 & 13.100 .000 \\
\hline Guerra na Síria & 560.000 & 0 \\
\hline
\end{tabular}

Fonte: BBC, 2017; CRAWFORD, 2016; HAGOPIAN et al, 2013; NYT, 2015; RTE, 2015; SOHR, 2018; THE GUARDIAN, 2017; UNHCR, 2019; WP, 2013. 


\section{OCIDENTALIZAÇÃO DOS DIREITOS HUMANOS E EXCLUSÕES ABISSAIS: ANÁLISE DAS PRÁTICAS DISCURSIVAS E DO EXERCÍCIO DO PODER NO DIREITO

Além dos custos humanos, o imperialismo consome uma grande quantidade de recursos financeiros. Para tornar possíveis os empreendimentos militares, o Ocidente desloca um vultoso montante de receita extraída dos tributos pagos pelos cidadãos para o custeio de armamento, transporte, inteligência e fortalecimento das instituições responsáveis pela segurança nacional, atingindo patamares exorbitantes.

Segundo Crawford (2017), as movimentações militares dos EUA no Afeganistão, no Iraque, no Paquistão e na Síria após o Nine Eleven, associadas aos gastos com o cuidado médico dos veteranos de guerra e ao orçamento do Departamento de Segurança Nacional custaram à população estadunidense aproximadamente 5,6 trilhões de dólares entre os anos de 2001 e 2018.

Neste ponto, com base no documento intitulado "Custo Estimado para Cada Contribuinte das Guerras no Afeganistão, no Iraque e na Síria" ${ }^{\text {, }}$, publicado periodicamente pelo Pentágono, em dados extraídos do Departamento de Tesouro norte-americano e de estimativas providas por outros pesquisadores, o autor estima que os conflitos custaram aproximadamente US\$ $23.386,00{ }^{17}$ para cada cidadão estadunidense no mesmo período.

Tabela 2 - Detalhamento da estimativa de custos atualizada e de custos futuros da guerra sobre o orçamento dos Estados Unidos da América, com aproximação em bilhões.

\begin{tabular}{|c|c|}
\hline Custos com apropriações e dispêndios (AF2001-AF2017 ${ }^{18}$ ) & Bilhões \\
\hline Total do Departamento de Defesa (integralmente OCAM $^{19}$ ) & 1.758 \\
\hline Total do Departamento de Estado e US/AID ${ }^{20}$ (integralmente OCAM) & 120 \\
\hline
\end{tabular}

16 O documento publicado pelo Pentágono em 2017 pode ser consultado em: https://comptroller.defense.gov/Portals/45/Documents/defbudget/fy2018/Section_1090_FY17_NDAA_Cost_of_ Wars_to_Per_Taxpayer-July_2017.pdf.

${ }^{17}$ Os dados divulgados pelo Pentágono afirmam que o custo médio da guerra para cada cidadão contribuinte no período citado seria de aproximadamente US\$ 7.740,00. Entretanto, Crawford (2017) refuta a exposição oficial diante das demais parcelas de recurso destinadas indiretamente ao custeio dos conflitos, como é o caso do financiamento dos tratamentos médicos de veteranos e o pagamento pela contratação de serviços de inteligência e pela criação de novos postos de trabalho no âmbito do Departamento de Estado e do Departamento de Segurança Nacional.

${ }^{18}$ Em tradução livre, a sigla "FY", referente a "fiscal year", corresponde a "AF", isto é, "ano fiscal".

19 Do original “OCO" (Overseas Contingency Operations), traduziu-se o termo como Operações de Contingência Além-mar (OCAM). Essa modalidade de gasto público nos Estados Unidos é comumente associada aos gastos do país com movimentações militares em países como Afeganistão, Iraque, Paquistão e Síria.

${ }^{20}$ A Agência dos Estados Unidos para o Desenvolvimento Internacional (da sigla US/AID) é um organismo vinculado à Administração Federal estadunidense, cujo objetivo é auxiliar a condução da política externa dos EUA a partir da distribuição de auxílio de caráter civil a outros países. Apesar de seu escopo formal, a US/AID tem sido alvo de diversas acusações de tentativa de desestabilização de governos não alinhados aos interesses dos EUA, como no caso da criação do aplicativo de mensagens instantâneas ZunZuneo, destinado a estimular mobilizações populares organizadas contra o governo de Cuba. Também pesa sobre a agência a acusação de ter 


\begin{tabular}{|c|c|}
\hline Provisionamentos estimados para o orçamento “base” do Pentágono & 879 \\
\hline Total destinado a tratamento médico e de deficiências de veteranos & 277 \\
\hline Provisionamentos para o Departamento de Segurança Nacional & 783 \\
\hline Juros sobre as Apropriações de Guerra do Pentágono & 534 \\
\hline Subtotal de custos - AF2001-AF2017 & 4.351 \\
\hline Estimativas de gastos futuros & 67 \\
\hline Departamento de Defesa (integralmente OCAM, orçamento AF2018) & 33 \\
\hline Aumento estimado do orçamento base do Pentágono devido à guerra & 3 \\
\hline Departamento de Estado/USAID (integralmente OCAM, orçamento AF2018) & 70 \\
\hline Segurança Nacional para prevenção e resposta ao terrorismo, orçamento AF2018 & 20 \\
\hline Tratamento médico e de deficiências de veteranos, orçamento para AF2018 & 88 \\
\hline Juros estimados sobre os empréstimos para custeio de guerras, AF2018 & 1.000 \\
\hline Tratamento médico e de deficiências de futuros veteranos, AF2019-2056 & 1.281 \\
\hline Subtotal de gastos futuros relativos à guerra & $\underline{\mathbf{5 . 6 3 2}}$ \\
\hline Total de custos atual e custos futuros estimados sobre o Orçamento Federal & $\mathbf{7 . 9 0 0 +}$ \\
\hline Juros cumulativos até 2056 sobre apropriações para a guerra desde AF2013 & \\
\hline
\end{tabular}

Fonte: CRAWFORD, 2017.

Crawford (2017) ainda afirma que diversos outros gastos não estão incluídos nesta estimativa, como aqueles não subsidiados pelo governo federal estadunidense (destacam-se os gastos com cuidados médicos de veteranos em âmbito local, regional e estadual), além das doações dos Estados Unidos para os países em zonas de guerra ${ }^{21}$ e dos valores gastos pelos aliados dos EUA nestes mesmos conflitos.

Diante da exaustiva ocorrência e permanência dos conflitos bélicos, políticos e sociais nos países atingidos pela atuação discursiva, jurídica e militar do Ocidente, é perceptível que a expressiva alocação de recursos para a suposta resolução desse cenário não é a solução adequada ao problema. Mais que isso, a perpetuação do modus operandi até então vigente demonstra um desinteresse dos países imperialistas na real pacificação dos enfrentamentos, na medida em que a aniquilação da dissidência aos padrões ocidentais pela via da maximização das conflagrações tem se revelado eficiente. 


\section{OCIDENTALIZAÇÃO DOS DIREITOS HUMANOS E EXCLUSÕES ABISSAIS: ANÁLISE \\ DAS PRÁTICAS DISCURSIVAS E DO EXERCÍCIO DO PODER NO DIREITO

Sendo assim, cabe a reflexão acerca da origem e do destino desse numerário. Ao cabo, a população é a financiadora das ações deflagradas à custa desses recursos, enquanto que os povos "outros", em tese beneficiários da atuação humanitária, são as vítimas do extermínio desencadeado direta e indiretamente pelos valores da guerra.

\section{Ultrapassando a linha abissal}

As discussões empreendidas nas seções anteriores oferecem um prognóstico um tanto quanto desanimador. Não obstante, pensamos que a superação dos ideais de uniformização planetária veiculados pelo orientalismo e a reversão dos efeitos da ocidentalização demandam a ativação de duas iniciativas.

A primeira delas, de natureza interna, consiste na necessidade de um processo de interculturalização (MARRAMAO, 2018; SANTOS, 2009) a partir do próprio Ocidente, pelo qual sejam revitalizados valores existenciais coletivos em detrimento de interpretações suprematistas da cultura ocidental.

Nesse processo, exige-se a adoção de uma ótica subjetivante (HERRERA FLORES, 2005) para desmantelar os referenciais de objetivação e padronização dos indivíduos e passar a concebê-los como atores no palco existencial, assegurando-lhes o direito de existir enquanto protagonistas, e não meros expectadores, nas relações sociais.

A expansão da experiência histórica do Ocidente demanda que se dê voz àquelas experiências que foram estigmatizadas ou esquecidas por não estarem em conformidade com os objetivos imperialistas ou orientalistas prevalentes no capitalismo moderno, no sentido de explicitar que "muitos dos problemas que hoje confrontam o mundo resultam não só do desperdício de experiência que o Ocidente impôs ao mundo à força, mas também do desperdício de experiência que ele impôs a si mesmo de modo a sustentar a própria imposição sobre os outros" (SANTOS, 2009, p. 106).

É com base nessa sociologia das ausências, em que a suposta falta de experiência dos não existentes é transformada no desperdício da experiência dos invisíveis (SANTOS, 2002), entendemos possível uma reconcepção do Ocidente não mais enquanto dominador, mas como igualmente coabitante do espaço social em nível global. Trata-se de um exercício radical de reavaliação e modificação das estruturas mundiais de poder, é a partir dele que se verifica plausível postular um Ocidente "não ocidentalista".

A segunda iniciativa parte de um necessário exercício de humildade pelos Estados. A pretensa universalidade do direito internacional moderno (cuja solidez procuramos 


\section{OCIDENTALIZAÇÃO DOS DIREITOS HUMANOS E EXCLUSÕES ABISSAIS: ANÁLISE DAS PRÁTICAS DISCURSIVAS E DO EXERCÍCIO DO PODER NO DIREITO

indagar nesse trabalho) tem sido executada a partir de pesos e medidas diversos, tendo em conta que os Estados que ostentam maior proeminência na cena econômico-militar têm sido capazes de impor seus interesses em face dos demais países.

Daí a necessidade de desconstruir a noção de superioridade cultural que tem dado às nações "mais evoluídas" a tarefa de levar a democracia e o progresso ao resto do mundo, uma vez que não há parâmetros objetivos para definir o alcance desses objetivos e que

[...] quando democracia quer dizer algo mais amplo, como o controle genuíno da tomada de decisões pela maioria da população na estrutura governamental, a capacidade real e constante de qualquer tipo de minoria exprimir-se política e culturalmente e a aceitação da legitimidade e da necessidade constante do debate político aberto, parece bastante claro que essas condições precisam amadurecer internamente nos diversos países e regiões e que, em geral, a intervenção externa é contra-indicada por associar o conceito de democracia ao controle externo e aos fatores negativos provocados pela intervenção. (WALLERSTEIN, 2007, p. 58-59)

No mesmo passo, é preciso desfazer o padrão enviesado do conceito de igualdade que se busca fazer valer de maneira global, à vista de que as condições materiais de acesso aos bens existenciais não estão distribuídas de maneira uniforme. Pelo contrário, as possibilidades de existência, para além dos marcadores sociais da diferença, também se encontram restritas ao redor do mundo a partir de critérios como a cultura, a religião e o território.

No âmbito específico do direito internacional, esse exercício de humildade demandaria reformular a concepção dos espaços de autoridade, em especial do Conselho de Segurança, no que a supressão do direito de veto ou a instituição de uma ferramenta de contestação da legalidade das Resoluções do colegiado seriam alternativas viáveis (MAZERON, 1997), bem como uma reavaliação da responsabilidade de proteger, com base na qual os potenciais interventores se ativessem aos perigos da falta de dados ou da disseminação de informações incorretas e dos riscos de potencialização das rebeliões.

Além disso, evitar a demonização dos mandatários sob questionamento seria uma ferramenta eficaz para facilitar o processo de negociação no curso da intervenção e para diminuir os índices de violência e mortalidade (HOLBROOKE, 1999; KUPERMAN, 2013). Se procedentes essas iniciativas, uma concepção não ocidentalista dos direitos humanos exige que elas sejam adotadas em conjunto. Isso porque a desconstrução das regularidades discursivas orientalistas e o desfazimento da linha abissal envolvem não só uma radicalização 


\section{OCIDENTALIZAÇÃO DOS DIREITOS HUMANOS E EXCLUSÕES ABISSAIS: ANÁLISE \\ DAS PRÁTICAS DISCURSIVAS E DO EXERCÍCIO DO PODER NO DIREITO

dos processos de subjetivação, mas também uma reformulação substancial das instituições jurídicas que governam o reconhecimento e a aplicação desses mesmos direitos.

\section{Conclusão}

Considerando a natureza multifocal do orientalismo, seria inviável analisar o seu acontecimento de maneira sistemática sem que se recorresse a uma pluralidade de disciplinas, das quais aqui se destacam o Direito, a Filosofia, as Relações Internacionais, a História, a Sociologia, a Linguística e a Comunicação.

No processo de condução da pesquisa, identificamos uma dispersão dos conteúdos relacionados ao tema por essas áreas do conhecimento. Por isso mesmo, a intenção primordial desse artigo era concentrar as evidências mais contundentes a respeito do fenômeno analisado e articulá-las a partir de um modelo analítico interdisciplinar, pelo qual pudéssemos estabelecer correlações entre os substratos empíricos coletados e traçar inferências descritivas e causais a partir deles.

Com a conclusão das análises, acreditamos que os resultados obtidos são relevantes para problematizar o que chamamos de ocidentalização de direitos humanos, que se revela de maneira mais latente nas disparidades brutais que transparecem nos processos de subjetivação dos indivíduos que habitam "o Oriente", nos regimes de veridicção que ditam os critérios de inteligibilidade da vida digna e nas regularidades discursivas que arregimentam o direito internacional em prol dos interesses ocidentais à custa das vidas consideradas irrelevantes.

O substrato empírico analisado revela, de um lado, uma forte influência da comunicação midiática na reificação dos processos de desumanização das vidas deslocadas do paradigma ocidental de existência. De fato, as regularidades discursivas que estabelecem uma associação direta entre o mundo não ocidental e o perigo não só estão imbricadas no discurso dos governantes, mas são também difundidas de maneira contundente pela mídia de massa, provocando uma organização de sentido da opinião pública.

Por outro lado, a história recente do Direito Internacional e da guerra contra "o Terror" demonstram, em certa medida, uma captura dos espaços institucionais de poder em âmbito global, bem como um significativo direcionamento orçamentário das potências ocidentais (em especial dos Estados Unidos) para o custeio dos conflitos.

Nesse cenário, o saldo das mortes em atentados terroristas, quando comparado com o número de óbitos resultantes das iniciativas bélicas promovidas ou financiadas pelo 


\section{OCIDENTALIZAÇÃO DOS DIREITOS HUMANOS E EXCLUSÕES ABISSAIS: ANÁLISE \\ DAS PRÁTICAS DISCURSIVAS E DO EXERCÍCIO DO PODER NO DIREITO

Ocidente, descortina uma disparidade na valoração das vidas perdidas, na medida em que o luto pelas existências afastadas do ideário ocidental de dignidade tem sido acolhido de maneira muito menos significativa a despeito da discrepância na contabilidade das mortes.

Diante disso, esperamos que as conclusões alcançadas pelo trabalho sirvam como evidência material para a denúncia do pensamento abissal, deflagrando narrativas que não se resumam a reivindicar uma universalidade formal, mas que tencionem de maneira concreta uma reconcepção multicultural dos direitos humanos emergida do abismo.

\section{Referências}

AKBARZADEH, Shahram; SMITH, Bianca. The representation of Islam and Muslims in the media. Clayton: Monash University Press, 2005.

\section{ALJAZEERA CENTRE FOR STUDIES. Media Coverage of the Paris and Brussels} Attacks - What was Different?. Disponível em:

http://studies.aljazeera.net/mritems/Documents/2016/4/3/7d56d2851cd04afbbd5d603fafaa194 5_100.pdf. Acesso em: 20 fev. 2020.

ALSULTANY, Evelyn. Arabs and Muslims in the media: Race and representation after 9/11. Nova Iorque: University Press, 2012.

\section{ALTO COMISSARIADO DAS NAÇÕES UNIDAS PARA OS REFUGIADOS. Syria}

Emergency. Disponível em: https://www.unhcr.org/syria-emergency.html. Acesso em: 20 jan. 2020.

ARAÚJO, Sara. O primado do direito e as exclusões abissais: reconstruir velhos conceitos, desafiar o cânone. Sociologias, Porto Alegre, n. 43, p. 88-115, set./dez. 2016.

BAUMAN, Zygmunt. Tempos líquidos. Rio de Janeiro: Jorge Zahar Ed., 2007.

BBC. Spain attack: What do we know about the victims?. Disponível em:

https://www.bbc.com/news/world-europe-40973119. Acesso em: 10 mar. 2020.

BIBLIOTECA VIRTUAL DE DIREITOS HUMANOS DA USP. Pacto da Sociedade das Nações. Disponível em: http://honoriscausa.weebly.com/uploads/1/7/4/2/17427811/55__pacto_da_sociedade_das_nacoes.pdf. Acesso em: 21 mar. 2020.

BUCHANAN, Allen; KEOHANE, Robert O. The Preventive Use of Force. In: KINSELLA, David; CARR, Craig L. (eds.). The Morality of War: a Reader. Boulder, CO: Lynne Rienner, 2007.

CHOMSKY, Noam. Mídia: Propaganda política e manipulação. São Paulo: Martins Fontes, 2014.

CHOMSKY, Noam. Who rules the world?. Nova York: Metropolitan Books, 2016. 
CORTE INTERNACIONAL DE JUSTIÇA. Case concerning military and paramilitary activities in and against Nicaragua - Jurisdiction of the Court and Admissibility of the Application - Judgement of 26 November 1984. Disponível em: https://www.icjcij.org/en/case/70/judgments. Acesso em: 22 mar. 2020.

CORTE INTERNACIONAL DE JUSTIÇA. Case concerning military and paramilitary activities in and against Nicaragua - Merits - Judgement of 27 June 1986. Disponível em: http://www.worldlii.org/int/cases/ICJ/1986/1.html. Acesso em: 22 mar. 2020.

CRAWFORD, Neta C. United States Budgetary Costs of Post-9/11 Wars Through FY2018: A Summary of the \$5.6 Trillion in Costs for the US Wars in Iraq, Syria, Afghanistan and Pakistan, and Post-9/11 Veterans Care and Homeland Security. Costs of War. Disponível em:

https://watson.brown.edu/costsofwar/files/cow/imce/papers/2017/Costs\%20of\%20U.S.\%20Po st-9_11\%20NC\%20Crawford\%20FINAL\%20.pdf. Acesso em: 10 mar. 2020.

CRAWFORD, Neta C. Update on the Human Costs of War for Afghanistan and Pakistan, 2001 to mid-2016. Costs of War. Disponível em:

https://watson.brown.edu/costsofwar/files/cow/imce/papers/2016/War\%20in\%20Afghanistan \%20and\%20Pakistan\%20UPDATE_FINAL_corrected\%20date.pdf. Acesso em: 11 fev. 2020.

DELAHUNTY, Robert J.; YOO, John C. Executive Power v. International Law. Harvard Journal of Law and Policy, Cambridge, vol. 30, n. 1, p. 1-35, 2007.

DIAS, Caio Gracco Pinheiro. Contra a Doutrina "Bush": Preempção, Prevenção e Direito Internacional. 2007. 210 f. Tese (Doutorado em Direito) - Universidade de São Paulo, São Paulo, 2007.

ESTADOS UNIDOS DA AMÉRICA. American Service-members' Protection Act of 2002. Disponível em: https://legcounsel.house.gov/Comps/aspa02.pdf. Acesso em: 20 mar. 2020.

ESTADOS UNIDOS DA AMÉRICA. The National Security Strategy of the United States of America (2002). Disponível em:

https://www.state.gov/documents/organization/63562.pdf. Acesso em: 20 mar. 2020.

ESTADOS UNIDOS DA AMÉRICA. Uniting and Strengthening America by Providing Appropriate Tools Required to Intercept and Obstruct Terrorism (USA PATRIOT ACT) Act of 2001. Disponível em: https://www.gpo.gov/fdsys/pkg/BILLS107hr3162enr/pdf/BILLS-107hr3162enr.pdf. Acesso em: 20 mar. 2020.

FEDERAL BUREAU OF INVESTIGATION. Terrorism (2002-2005). Disponível em: https://www.fbi.gov/stats-services/publications/terrorism-2002-2005. Acesso em: 20 mar. 2020.

FOUCAULT, Michel. A Ordem do Discurso: aula inaugural no Collège de France, pronunciada em 2 de dezembro de 1970. 5. ed. São Paulo: Loyola, 1999.

FOUCAULT, Michel. A verdade e as formas jurídicas. Rio de Janeiro: Nau, 2005. 


\section{OCIDENTALIZAÇÃO DOS DIREITOS HUMANOS E EXCLUSÕES ABISSAIS: ANÁLISE DAS PRÁTICAS DISCURSIVAS E DO EXERCÍCIO DO PODER NO DIREITO

FOUCAULT, Michel. L'extensión sociale de la norme. In: FOUCAULT, Michel. Dits et écrits III. Paris: Gallimard, 1976.

FOUCAULT, Michel. Microfísica do poder. 13. ed. São Paulo: Paz e Terra, 1998.

GILBOA, Eytan. The CNN effect: The search for a communication theory of international relations. Political Communication, vol. 22, n. 1, p. 27-44, 2005.

GOLDSMITH, Jack L.; POSNER, Eric A. The Limits of International Law. Londres: Oxford University Press, 2006.

GOODY, Jack. The Theft of History. Nova York: Cambridge University Press, 2006.

GOTTSCHALK, Peter; GREENBERG, Gabriel. Islamophobia: Making Muslims the enemy. Lanham, MD: Rowman \& Littlefield, 2008.

HAGOPIAN, Amy et al. Mortality in Iraq Associated with the 2003-2011 War and Occupation: Findings from a National Cluster Sample Survey by the University Collaborative Iraq Mortality Study. PLoS Med, Ottawa, vol. 10, n. 10, p. 1-15, 2013. DOI:

https://doi.org/10.1371/journal.pmed.1001533. Disponível em:

https://journals.plos.org/plosmedicine/article?id=10.1371/journal.pmed.1001533. Acesso em: 20 mar. 2020.

HARDT, Michael; NEGRI, Antonio. Empire. Cambridge, Massachusetts: Harvard University Press, 2000.

HERRERA FLORES, Joaquín. De habitaciones propias y otros espacios negados: Una teoría crítica de las opresiones patriarcales. Bilbao: Universidad de Deusto, 2005. (Cuadernos Deusto de Derechos Humanos, n. 33).

HOLBROOKE, Richard. To End a War: The Conflict in Yugoslavia - America's Inside Story - Negotiating with Milosevic. Nova Iorque: Alfred A. Knopf, 1999.

INSTITUTE FOR ECONOMICS \& PEACE. Global Terrorism Index 2018: Measuring the impact of terrorism. Disponível em: http://visionofhumanity.org/app/uploads/2018/12/GlobalTerrorism-Index-2018-1.pdf. Acesso em: 19 fev. 2020.

KÖCHLER, Hans. Global Justice or Global Revenge?: International Criminal Justice at the Crossroads. Nova Iorque: Springer, 2004.

KEARNS, Erin M.; BETUS, Allison E; LEMIEUX, Anthony F. Why Do Some Terrorist Attacks Receive More Media Attention Than Others?, Justice Quarterly, Greenbelt, vol. 35, n. 6, p. 1-38, 2019. DOI: 10.1080/07418825.2018.1524507. Disponível em: https://www.tandfonline.com/doi/full/10.1080/07418825.2018.1524507. Acesso em: 30 jan. 2020.

KUPERMAN, Alan J. A Model Humanitarian Intervention?: Reassessing NATO's Libya Campaign. International Security, Boston, vol. 38, n. 1, p. 105-136, 2013. 
KUPERMAN, Alan J. The Moral Hazard of Humanitarian Intervention: Lessons from the Balkans. International Studies Quarterly, vol. 52, n. 1, p. 49-80, 2008.

LOBEL, Jules; RATNER, Michael. Bypassing the Security Council: Ambiguous Authorizations to Use Force, Cease-Fires and the Iraqi Inspection Regime. The American Journal of International Law, vol. 93, n. 1, p. 124-154, jan. 1999.

MARRAMAO, Giacomo. Universais em conflito: Identidade e Diferença na Era Global. Belo Horizonte: Conhecimento, 2018.

MAZERON, Florent. Le contrôle de légalité des décisions du Conseil de Sécurité - Un bilan après les ordonnances Lockerbie et l'arrêt Tadic. Revue québécoise de droit international, vol. 10, p. 105-136, 1997.

MURPHY, Sean D. The Doctrine of Preemptive Self-Defense. Villanova Law Review, vol. 50, p. 699-748, 2005.

NORHEIM-MARTINSEN, Per M. The Doctrine of Responsibility to Protect and the Use of Force. In: HAMANN, Eduarda P.; MUGGAH, Robert. Implementing the Responsibility to Protect: New Directions for International Peace and Security?. Brasília: Instituto Igarapé; Embaixada da Noruega, 2013.

ORGANIZAÇÃO DAS NAÇÕES UNIDAS. A Carta das Nações Unidas. Disponível em: https://nacoesunidas.org/carta/. Acesso em: 04 set. 2018.

ORGANIZAÇÃO DAS NAÇÕES UNIDAS. United Nations Documents. Disponível em: https://undocs.org/. Acesso em: 03 abr. 2020.

ORGANIZAÇÃO DAS NAÇÕES UNIDAS. Universal Declaration of Human Rights. Disponível em: http://www.un.org/en/universal-declaration-human-rights/. Acesso em: 04 set. 2017.

ORGANIZAÇÃO DAS NAÇÕES UNIDAS. Conselho de Segurança. Provisional Verbatim Record of the Two Thousand Seven Hundred and Fourth Meeting. Index: S/PV.2704, 31 jul. 1986. Disponível em: https://undocs.org/en/S/PV.2704. Acesso em: 22 jan. 2019.

ORGANIZAÇÃO DAS NAÇÕES UNIDAS. Conselho de Segurança. Resolução 1373. Index: S/RES/1373 (2001). Disponível em: https://undocs.org/S/RES/1373(2001). Acesso em: 22 jan. 2019.

PARK, Jaihyun; FELIX, Karla; LEE, Grace. Implicit attitudes toward Arab-Muslims and the moderating effects of social information. Basic \& Applied Social Psychology, vol. 29, n. 1, p. 35-45, 2007.

POPULATION RESEARCH INSTITUTE. USAID Supported Fujimori Sterilization Campaign; Seeks to Cover-Up Involvement. Disponível em: https://www.pop.org/usaidsupported-fujimori-sterilization-campaign-seeks-to-cover-up-involvement-3/. Acesso em: 20 dez. 2018. 
REISMANN, William Michael. Assessing Claims to Revise the Laws of War. The American Journal of International Law, vol. 97, n. 1, p. 82-90, 2003.

RTE NEWS. Paris attacks death toll rises to 130. Disponível em:

https://www.rte.ie/news/2015/1120/747897-paris/. Acesso em: 10 jul. 2018.

SAID, Edward W. Orientalismo: o Oriente como invenção do Ocidente. São Paulo: Companhia das Letras, 2007.

SALEEM, Muniba; ANDERSON, Craig A. Arabs as terrorists: Effects of stereotypes within violent contexts on attitudes, perceptions, and affect. Psychology of Violence, vol. 3, n. 1, p. 84-99, 2013.

SANTOS, Boaventura de Sousa. A Non-Occidentalist West?: Learned Ignorance and Ecology of Knowledge. Theory, Culture \& Society, Londres, vol. 26, n. 103, p. 103-125, 2009.

SANTOS, Boaventura de Sousa. Para uma sociologia das ausências e uma sociologia das emergências. Revista Crítica de Ciências Sociais, Coimbra, n. 63, p. 237-280, 2002.

SANTOS, Boaventura de Sousa. Toward a New Common Sense: Law, Science and Politics in the Paradigmatic Transition. Nova York: Routledge, 1995.

SLONE, Michelle. Responses to media coverage of terrorism. Journal of Conflict Resolution, vol. 44, n. 4, p. 508-522, 2000.

SORTO, Fredys Orlando. A Corte Internacional de Justiça e o caso Estados Unidos Nicarágua. Revista de Informação Legislativa, Brasília, n. 127, p. 233-239, jul./set. 1995.

STROMSETH, Jane. Rethinking humanitarian intervention: the case for incremental change. In: HOLZGREFE, J. L.; KEOHANE, Robert O (eds.). Humanitarian Intervention: Ethical, Legal and Political Dilemmas. Boston: Cambridge University Press, 2003.

SULTAN, Khalid. Linking Islam with terrorism: A review of the media framing since 9/11. Global Media Journal: Pakistan Edition, vol. 9, n. 2, p. 1-10, 2016.

SYRIAN OBSERVATORY FOR HUMAN RIGHTS. In about 93 months... about 560 thousand were killed in Syria since the day of claiming rights to the international human rights day. Disponível em: http://www.syriahr.com/en/?p=108723. Acesso em: 10 dez. 2018.

TERRY, Patrick C. R.; OPENSHAW, Karen. Nuclear Non-Proliferation and "Preventive Self-Defence": Why Attacking Iran would be Illegal. The Canadian Yearbook of International Law, vol. 51, p. 165-215, 2013.

THE GUARDIAN. Mogadishu truck bomb: 500 casualties in Somalia's worst terrorist attack. Disponível em: https://www.theguardian.com/world/2017/oct/15/truck-bombmogadishu-kills-people-somalia. Acesso em: 10 mar. 2020.

THE GUARDIAN. US secretly created 'Cuban Twitter' to stir unrest and undermine government. Disponível em: https://www.theguardian.com/world/2014/apr/03/us-cubantwitter-zunzuneo-stir-unrest. Acesso em: 20 mar. 2020. 
THE NEW YORK TIMES. ISIS Claims Responsibility for Blasts That Killed Dozens in Beirut. Disponível em: https://www.nytimes.com/2015/11/13/world/middleeast/lebanonexplosions-southern-beirut-hezbollah.html. Acesso em: 10 mar. 2020.

THE WASHINGTON POST. Nine facts about terrorism in the United States since 9/11. Disponível em: https://www.washingtonpost.com/news/wonk/wp/2013/09/11/nine-factsabout-terrorism-in-the-united-states-since-911/?noredirect $=$ on\&utm_term $=$. beb381ab03a0 . Acesso em: 10 mar. 2020.

WALLERSTEIN, Immanuel. O universalismo europeu: a retórica do poder. São Paulo: Boitempo Editorial, 2007.

WEIMANN, Gabriel; BROSIUS, Hans-Bernd. The newsworthiness of international terrorism. Communication Research, vol. 18, n. 3, p. 333-354, 1991.

Data de recebimento: 03.04.2020

Data de aprovação: 05.05.2020 